Katharina Knoop, Stefan Lechtenböhmer

\title{
The Potential for Energy Efficiency in the EU Member States - A Comparison of Studies
}

Originally published in:

Renewable and Sustainable Energy

Reviews, 68 (2017), 1097-1105

DOI: 10.1016/j.rser.2016.05.090 
Katharina Knoop, *

Stefan Lechtenböhmer

\section{The Potential for Energy Efficiency in the EU Member States - A Comparison of Studies}

Research Group Future Energy and Mobility Structures

Wuppertal Institute for Climate, Environment and Energy,

Doeppersberg 19, 42103 Wuppertal, Germany

* Corresponding author:

Katharina Knoop

E-mail: katharina.knoop@wupperinst.org

Phone: +49-202-2492-266

This is the author's version of a work that was accepted for publication. Changes resulting from the publishing process, such as editing, corrections and structural formatting, may not be reflected in this document. Changes may have been made to this work since it was submitted for publication. A definitive version was subsequently published in the Journal cited above. 


\title{
The Potential for Energy Efficiency in the EU Member States - A Comparison of Studies
}

\author{
Katharina Knoop*, Stefan Lechtenböhmer \\ Research Group Future Energy and Mobility Structures, Wuppertal Institute for Climate, \\ Environment and Energy, Doeppersberg 19, 42103 Wuppertal, Germany
}

\begin{abstract}
In October 2014, the European Council agreed on a target of improving overall energy efficiency by at least 27 per cent by 2030. According to the European Council's conclusions, this target should not be translated into nationally binding targets. Nevertheless individual Member States are free to set higher national objectives if desired. However, it is difficult to assess the degree of ambition of a national target because so far not much light has been shed upon the exact size of the untapped efficiency potentials.

This paper provides an in-depth analysis and comparison of existing studies on energy efficiency potentials in the European Union's (EU) Member States by 2030. It includes a structured overview of the results, information on the quality of the available data and suggestions for improvement.

The review shows that comprehensive studies on national energy efficiency potentials are rare and hardly comparable. The existing studies agree on the existence of significant potentials for energy efficiency. Their outcomes, however, vary significantly in terms of national levels. Assuming low policy intensity, energy savings between 10 and 28 per cent could be realised by 2030 compared to a baseline development, in the case of high policy intensity 7 to 44 per cent. Technical energy efficiency potentials in the different EU Member States are estimated at 14 to 52 per cent. On average, energy savings of 27 per cent by 2030 appear to be feasible with significant policy effort. We conclude that the deviation in Member States' energy efficiency potentials resulting from different studies represents an indication of the so far poor quality of underlying data. In order to allow for a concretisation of efficiency potential estimates, the comparability and detail of information sources should be improved.
\end{abstract}

\section{KEYWORDS}

Energy efficiency potential; energy saving; EU Member States; 2030 climate and energy targets; scenario analysis

\section{INTRODUCTION}

In order to achieve the European Union's (EU) target of a transition towards a more competitive, secure and sustainable energy system, "energy efficiency has a fundamental role to play" [1]. Similarly, energy efficiency measures are regarded by all relevant international organisations as a central means to realise greenhouse gas emission (GHG) reductions and related co-benefits such as better air quality and potential job growth worldwide, especially as

* Corresponding author. Tel. +49-202-2492-266. E-mail address: katharina.knoop@wupperinst.org 
a short-term strategy. Compared to other decarbonisation options, efficiency measures are often quickly to implement, cost-effective and already widely available today [2].

In order to achieve a widespread implementation and to exploit the various advantages linked to energy efficiency improvements, the EU adopted several plans and laws on energy efficiency, particularly in the past decade.

An important recent policy is the Energy Efficiency Directive (EED, 2012/27/EU), which was enacted in 2012. In order to achieve the EU's 20 per cent primary energy savings target by 2020, all Member States are required to cut their final energy consumption by at least 1.5 per cent per year from 2014 to 2020 and to notify indicative national energy efficiency targets to be achieved by 2020 [3].

The European Council set climate and energy targets for 2030 in October 2014. The decision included an indicative target of at least 27 per cent for improving energy efficiency in the EU as a whole compared to baseline projections for future energy consumption [4]. The target might be scaled up to $30 \%$ by no later than 2020. Although the European Council does not intend to translate the target into nationally binding targets, individual Member States are encouraged to set higher national objectives.

Thus, from an overall perspective it seems clear that ambitious targets as well as bold policies should be pursued by all EU Member States to harness the multiple benefits of energy efficiency, in the long as well as in the short term. Moreover, these policies should be harmonized to a certain extent to make use of potential synergies and avoid duplication of efforts. In order to independently benchmark national future energy efficiency targets, it would be necessary to a) have national targets defined in a comparable, transparent and verifiable manner and to $b$ ) have a sound knowledge of the existing potentials for energy efficiency in the different Member States and sectors. However, neither a) nor b) is as straightforward as it may seem.

Firstly, in accordance with the legal requirements, the Member States' energy efficiency targets for 2020 which have been notified to the Commission [5] differ, e.g. in terms of target items (primary/final energy consumption/savings, energy intensity) and reference points (historical base year/baseline scenario). The fact that no precise definition was fixed to determine and monitor national efficiency targets makes a comparison in a political context not meaningful [6]. If voluntary national efficiency targets are set for 2030, they will most probably also vary with regard to the definitions and metrics used.

Secondly, despite common belief, data on national (regional) energy efficiency potentials in the EU is generally poorly available or accessible. In fact, most studies on energy efficiency potentials cover only certain technologies, sectors and/or countries. Regarding the geographical focus, studies currently often concentrate on energy efficiency potentials in emerging or developing countries (e.g. [7], [8], [9], [10]), especially in Asia, as many of these countries are expected to experience comparatively strong increases in energy consumption due to economic and population growth. With respect to sectors and technologies, the focus is mostly laid on those which consume most energy, i.e. energy-intensive industries and buildings ([11], [12], [13], [14]) or heating/cooling and lighting ([15], [16], [17]). If national efficiency potentials are available, e.g. in the framework of National Energy Efficiency Action Plans (NEEAPs), they state short-term efficiency potentials, e.g. for 2016 in the 2011 NEEAPs.

Although the available studies agree on the existence of significant national efficiency potentials, so far not much light has been shed on the extent of untapped (especially longterm) energy efficiency potentials in the different EU Member States. Therefore, we critically 
analyse the information available on the potentials for energy efficiency in the different EU Member States for 2030. In this way, we try to give first indicative answers to the questions of how to best determine the extent of energy efficiency potentials and how to benchmark national energy efficiency targets. Furthermore, we appraise the quality of the available data and try to derive hints on how to improve.

In the following, the method chosen to determine energy efficiency potentials and the availability of data on this topic are first described. Furthermore, a brief classification of different types of energy efficiency potentials is provided. The next section presents a structured overview of the results of existing EU-wide studies with national results on (dynamic) final energy savings potentials for the year 2030. Further to this, we analyse a number of national studies and state the implied energy efficiency potentials by comparing the latest available submissions of Member States to the EU's climate policy Monitoring Mechanism. In the following section, the results are discussed. Conclusions drawn from the analysis can be found in the final section.

\section{MATERIAL AND METHOD}

Although "no one unequivocal quantitative measure" exists for national energy efficiency potentials [18], energy efficiency is usually broadly defined as the "useful output of a process" divided by "energy input into a process" [18]. According to this definition, energy efficiency improvements differ from mere energy savings in so far as it is assumed that the same output can be achieved as before, only with lower energy inputs. A country's energy efficiency potential thus equals the amount of energy inputs a country is able to save by implementing energy efficiency measures while maintaining the same level of useful output. Due to the fact that many different factors and assumptions or "dimensions of energy efficiency" [6] influence the calculation of efficiency potentials, the best approach to determine national energy efficiency potentials is to conduct a thorough bottom-up study. However, this would require enormous effort, given that hundreds of cases on areas of energy end use and concrete technologies, including trends for their application, would have to be covered and combined using a coherent methodology. Moreover, no recent studies of this type (which could provide a data base for such work) were available for the EU Member States at the time of writing this article. ${ }^{1}$

For the purpose of this paper, energy efficiency potentials for the different EU Member States in 2030 are determined on the basis of data provided in publicly available literature and reports. As a proxy for national potentials we use the difference between final energy demand projections in two future scenarios for 2030 - one scenario with and one without energy efficiency technologies and measures being assumed. Although the determination of the difference between two scenarios is regularly used to approximate the extent of national energy saving potentials (e.g. by [20], [21]) it does imply weaknesses.

First, there is a general uncertainty inherent in every scenario. Second, macroeconomic data is often imprecise owing to varying conditions in terms of climate, economy (e.g. business cycle, crisis, prices) and structure. Due to the variety of influences, it proves difficult to disaggregate this data and relate changes in energy efficiency directly to individual factors [22]. For example, in the industrial and tertiary sector, structural effects such as a greater shift from the industrial to the tertiary sector play an important role [23]. Furthermore, it is unclear in how far potential rebound effects are considered in the scenarios, i.e. which proportion of

\footnotetext{
${ }^{1}$ A new bottom-up study has been published by Fraunhofer ISI el al. at the end of 2014 [19].
} 
the efficiency improvement is counteracted by individuals consuming more of the product (e.g. driving more in a fuel-efficient car) or of other products. Besides, baseline scenarios typically already include so-called "autonomous" improvements in energy efficiency, due to the development of policies as well as trends in the fields of technology, macroeconomics, prices and society. Since these assumptions vary significantly from study to study, so do the resulting efficiency gains included in the baseline scenario and subsequently also the remaining potentials to be exploited by policy. One (but not the only) important reason for differences between studies is that they have been conducted at different points in time. As a result, the policies and economic trends prevailing at the time of making differ (e.g. before or after unexpected developments such as the economic and financial crisis). We try to control for deviations resulting from varying assumptions in the scenario modelling process by always comparing two scenarios from the same study. Therefore, only studies including a reference scenario as well as a scenario considering ambitious energy efficiency improvements are taken into account.

For our analysis we used three different types of sources of information on national energy efficiency potentials for different EU Member States:

- EU-wide (scenario) studies (commissioned by DG TREN ([24], [25], [26]), the German Federal Ministry for the Environment, Nature Conservation and Nuclear Safety [27], the European Climate Foundation (ECF)/Regulatory Assistance Project (RAP) [28] and Greenpeace/EREC [29]). The advantage of these studies is that they cover all Member States in a comparable methodology and use a consistent set of assumptions for the two scenarios for all Member States. It should be noted that some studies rely on data collected within other studies, meaning that the more recent study represents an update of an earlier study and does not include new, independently gathered data but rather recalculations accounting for updated information, e.g. on energy price or GDP projections (e.g. both Fraunhofer ISI 2012 [27] and Ecofys, Fraunhofer ISI 2010 [28] are based on Fraunhofer ISI et al. 2009 [24]) (see Table 2 and Figure 1).

- Official projections provided by national governments as part of their submissions to the EU GHG Monitoring Mechanism (Decision No 280/2004/EC) [30] also provide information on potentials for energy efficiency. Information on potentials is typically derived by national governments from national studies or internal estimates (which are not always easily accessible). According to the guidelines set out in the Monitoring Mechanism, the official projections of future GHG emissions shall include figures for expected final energy demand in two scenarios, "with existing measures" and "with additional measures". These scenarios compare with reference and more ambitious energy efficiency scenarios in the other analysed scenario studies. Many submissions, however, lack the data required for our analysis (see Table 3).

- Finally, a small number of national studies on final energy efficiency potentials are available, most of which were commissioned by national governments. The available studies analyse potential future developments of energy supply and demand by 2030 in Germany, France and the UK. Further researched national studies on the EU Member States, such as National Energy Efficiency Action Plans (NEEAPs), did not include sufficient data to derive national efficiency potentials for 2030 (see Table 4).

In order to be able to classify energy efficiency potentials derived from the different sources, they will be differentiated depending on the core assumptions underlying their efficiency scenarios. Concurrent with Fraunhofer ISI el al. 2009 [24] we classify energy efficiency potentials on the basis of two dimensions, the speed of technology diffusion and the level of 
restrictions on energy saving potentials. Both dimensions are subject to energy efficiency policies. The resulting categories are technical efficiency potential (assuming an almost complete exploitation of potentials due to a full removal of economic restrictions as well as reduced transaction costs and a fast technology diffusion because of removed barriers), high policy intensity (HPI) or low policy intensity (LPI) potentials for intermediate scenarios (Table 1).

Nevertheless, it should be kept in mind that these categories cannot always be clearly distinguished, and even if studies refer to the same type of potential, the underlying assumptions may differ considerably from study to study.

Table 1. Classification of energy saving potentials

\begin{tabular}{|c|c|c|c|c|c|}
\hline & & \multirow{2}{*}{ Baseline } & \multicolumn{3}{|c|}{ Energy efficiency potentials compared to baseline } \\
\hline & & & LPI potential & HPI potential & Technical potential \\
\hline & & $\begin{array}{l}\text { Lack of additional } \\
\text { efficiency policies in } \\
\text { the future results } \\
\text { in... }\end{array}$ & $\begin{array}{l}\text { Low policy intensity } \\
\text { regarding energy } \\
\text { efficiency results in... }\end{array}$ & $\begin{array}{l}\text { High policy intensity } \\
\text { regarding energy } \\
\text { efficiency results in... }\end{array}$ & $\begin{array}{l}\text { Use of policies and } \\
\text { best available } \\
\text { technologies results } \\
\text { in... }\end{array}$ \\
\hline \multirow{2}{*}{ 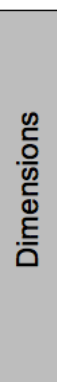 } & $\begin{array}{l}\text { Speed of } \\
\text { (efficient) } \\
\text { technology } \\
\text { diffusion }\end{array}$ & $\begin{array}{l}\text { slow (autonomous) } \\
\text { diffusion }\end{array}$ & $\begin{array}{l}\text { medium-speed } \\
\text { diffusion } \\
\text { (high barriers/ } \\
\text { high transaction cost) }\end{array}$ & $\begin{array}{l}\text { fast diffusion } \\
\text { (low barriers/ } \\
\text { low transaction cost) }\end{array}$ & $\begin{array}{l}\text { fast diffusion } \\
\text { (low barriers/ } \\
\text { low transaction cost) }\end{array}$ \\
\hline & $\begin{array}{l}\text { Level of } \\
\text { restrictions } \\
\text { on energy } \\
\text { saving } \\
\text { potentials }\end{array}$ & $\begin{array}{l}\text { high restrictions: } \\
\text { economic potential } \\
\text { (cost-effectiveness } \\
\text { for the consumer } \\
\text { with usual market } \\
\text { conditions) }\end{array}$ & $\begin{array}{l}\text { high restrictions: } \\
\text { economic potential } \\
\text { (cost-effectiveness for } \\
\text { the consumer with } \\
\text { usual market } \\
\text { conditions) }\end{array}$ & $\begin{array}{l}\text { medium-level } \\
\text { restrictions: } \\
\text { economic potential } \\
\text { (cost-effectiveness for } \\
\text { the national } \\
\text { economy) }\end{array}$ & $\begin{array}{l}\text { low restrictions: } \\
\text { technical potential } \\
\text { (use of best available } \\
\text { technologies and } \\
\text { practices) }\end{array}$ \\
\hline
\end{tabular}

Source: Own table based on Fraunhofer ISI et al. 2009 [24]

\section{RESULTS}

In the following, the three different types of studies (EU-wide scenario studies, Member States' submissions to the Monitoring Mechanism; national studies) will be analysed with regard to the national energy efficiency potentials they imply for 2030. Subsequently, the results of the three different sources of information will be compared.

\subsection{Energy efficiency potentials according to EU-wide studies}

Table 2 provides an overview of existing studies for the EU 27 as a whole (since most studies provide no data for Croatia, it was not included in this analysis). The scenarios considered are classified according to the type of potential they represent. The table also provides

information about the cost-effectiveness of the technologies considered. In addition to overall potentials, all studies listed provide a division into the main demand sectors such as industry, tertiary, residential and transport. The types of potentials given are essentially comparable; they are all either "technical" or they are politically realisable under so-called "high" or "low" 
policy intensities. They differ, however, regarding their baseline projections, mainly because some studies take into account the effects of the financial crisis while older ones do not ${ }^{2}$. Energy efficiency potentials are given for all scenarios as relative savings compared to the study's respective baseline scenario for 2030. If available, results for particular Member States are given further down in Figure 1.

As Table 2 shows, five EU-wide studies focussing on energy efficiency potentials are available, with the German Fraunhofer Institute for Systems and Innovation Research (Fh ISI) co-authoring four of them. Energy efficiency potentials indicated for the EU 27 as a whole are between $18 \%$ in one LPI scenario and $41 \%$ in the technical potential scenarios with the HPI scenarios indicating an intermediate value of $30 \%$. The studies by Greenpeace/EREC and TRT/Fh ISI are both indicating potentials at the lower end of their group. In the case of the first study, this is due to an already very ambitious baseline scenario. For the individual EU Member States, all studies expect huge deviations of around 10 percentage points from the EU 27 average.

Table 2. Classification and general results on final energy efficiency potentials of scenario studies considered

\begin{tabular}{|c|c|c|c|c|}
\hline $\begin{array}{l}\text { Type of } \\
\text { Potential }\end{array}$ & Scenario/study & $\begin{array}{l}\text { Information regarding } \\
\text { cost-effectiveness }\end{array}$ & $\begin{array}{l}\text { Economic } \\
\text { crisis } \\
\text { considered }\end{array}$ & $\begin{array}{l}\text { Final energy } \\
\text { efficiency potential } \\
\text { by } 2030 \text { in \% *) }\end{array}$ \\
\hline \multirow{3}{*}{ Technical } & Fh ISI 2012 & $\begin{array}{l}\text { Economic and almost } \\
\text { economic technologies } \\
\text { are considered }\end{array}$ & $\begin{array}{l}\text { Potentials } \\
\text { "adjusted" to } \\
\text { crisis }\end{array}$ & $\begin{array}{l}\text { EU 27: } 41 \\
\left.\text { Range }^{*}\right): 31-48\end{array}$ \\
\hline & $\begin{array}{l}\text { Fh ISI et al. } 2009- \\
\text { Technical scenario }\end{array}$ & $\begin{array}{l}\text { Includes measures that } \\
\text { are not cost-effective }\end{array}$ & No & $\begin{array}{l}\text { EU 27: } 41 \\
\left.\text { Range }^{*}\right): 24-52\end{array}$ \\
\hline & $\begin{array}{l}\text { Greenpeace/EREC } \\
2012\end{array}$ & -- & Yes & $\begin{array}{l}\left.\text { EU 27: } 23^{\star \star}\right) \\
\left.\text { Range }^{\star}\right): 14-33\end{array}$ \\
\hline \multirow{3}{*}{$\begin{array}{l}\text { High } \\
\text { policy } \\
\text { intensity } \\
\text { (HPI) }\end{array}$} & Ecofys/Fh ISI 2010 & $\begin{array}{l}\text { Cost-effective from a life } \\
\text { cycle perspective }\end{array}$ & $\begin{array}{l}\text { Not in } \\
\text { baseline, but } \\
\text { in HPI } \\
\text { scenario }\end{array}$ & $\begin{array}{l}\text { EU 27: } 30 \\
\left.\text { Range }^{*}\right): 15-44\end{array}$ \\
\hline & $\begin{array}{l}\text { Fh ISI et al. } 2009- \\
\text { HPI scenario }\end{array}$ & $\begin{array}{l}\text { Cost-effective for the } \\
\text { whole country }\end{array}$ & No & $\begin{array}{l}\text { EU 27: } 30 \\
\left.\text { Range }^{\star}\right): 15-44\end{array}$ \\
\hline & TRT/Fh ISI 2010 & -- & $\begin{array}{l}\text { Not in } \\
\text { baseline, but } \\
\text { in HPI } \\
\text { scenario }\end{array}$ & $\begin{array}{l}\text { EU 27: } 20 \\
\text { Range: } 7-26\end{array}$ \\
\hline $\begin{array}{l}\text { Low policy } \\
\text { intensity } \\
\text { (LPI) }\end{array}$ & $\begin{array}{l}\text { Fh ISI et al. } 2009- \\
\text { LPI scenario }\end{array}$ & $\begin{array}{l}\text { Cost-effective for } \\
\text { consumers "with usual } \\
\text { market conditions" }\end{array}$ & No & $\begin{array}{l}\text { EU 27: 18 } \\
\text { Range: } 10-28\end{array}$ \\
\hline
\end{tabular}

*) Lowest and highest potential for one EU Member State.**) although relative efficiency potentials from Greenpeace/EREC 2012 appear to be rather low, they are considered to be technical/HPI potentials because the study already assumes comparatively large energy demand savings in its baseline scenario

Source: Own table, studies analysed: [24], [25], [26], [27], [28], [29], [31], [32], [33], [34], [35]

\footnotetext{
${ }^{2}$ Studies performed after the economic and financial crisis rather assumed lower future energy consumption but also considered the crisis' impact in their baseline scenario. We control for this effect by using relative instead of absolute final energy savings between baseline and policy scenarios (see above).
} 


\subsection{Energy efficiency potentials according to national submissions to the EU GHG Monitoring Mechanism}

An overview illustrating the availability of data from reports submitted under the Monitoring Mechanism in 2013 is given in Table 3. If final energy demand projections exist, the resulting potentials are also given in the table.

This overview shows that the expected energy efficiency potentials for the 10 EU Member States that provided such data and that, together, account for about two thirds of the 20 considered countries' energy demand in 2010 ( 7 Member States provided no data for the base year) are quite moderate. Their average projected final energy demand savings amount to only 8.3 per cent by 2030 .

Table 3. Energy efficiency potential in EU Member States according to 2013 Monitoring Mechanism reports

\begin{tabular}{|c|c|c|c|c|c|c|}
\hline \multirow{3}{*}{ Country } & \multicolumn{3}{|c|}{$\begin{array}{l}\text { Final energy demand in end-use sectors } \\
\text { in ktoe }\end{array}$} & \multirow{3}{*}{$\begin{array}{l}\text { Potential } \\
\text { in ktoe by } \\
2030\end{array}$} & \multirow{3}{*}{$\begin{array}{l}\text { Potential } \\
\text { in } \% \text { by } \\
2030\end{array}$} & \multirow{3}{*}{ Comment } \\
\hline & \multirow[b]{2}{*}{$\begin{array}{l}\text { Historic } \\
\text { value: } 2010\end{array}$} & \multicolumn{2}{|c|}{ Scenario 2030} & & & \\
\hline & & $\begin{array}{l}\text { "With } \\
\text { existing } \\
\text { measures" }\end{array}$ & $\begin{array}{l}\text { "With } \\
\text { additional } \\
\text { measures" }\end{array}$ & & & \\
\hline Austria & 25,487 & 28,147 & 25,586 & 2,561 & 9.10 & 2011 report \\
\hline Belgium & 33,761 & No data for & 030, no data for & cenario "with & additional m & easures" \\
\hline Bulgaria & \multicolumn{6}{|c|}{ Accompanying report contains no data to calculate a potential } \\
\hline Cyprus & \multicolumn{6}{|c|}{ No submission in 2013,2011 data not publicly available } \\
\hline Czech Rep. & 25,946 & 26,135 & 25,380 & 755 & 2.89 & \\
\hline Denmark & \multicolumn{6}{|c|}{ No data publicly available } \\
\hline Estonia & 2,711 & \multicolumn{5}{|c|}{ Only data until 2020} \\
\hline Finland & 14,433 & 18,047 & 17,371 & 677 & 3.75 & \\
\hline France & 134,832 & 129,901 & 111,410 & 18,491 & 14.23 & \\
\hline Germany & 216,373 & 194,800 & 175,111 & 19,689 & 10.11 & \\
\hline Greece & 22,260 & \multicolumn{5}{|c|}{2009 report, no data for 2030 , no scenarios indicated } \\
\hline Hungary & 13,339 & \multicolumn{5}{|c|}{2011 report, no data for 2030} \\
\hline Ireland & 11,655 & 14,777 & 13,199 & 1,578 & 10.68 & \\
\hline Italy & 126,812 & 133,962 & 123,637 & 10,325 & 7.71 & \\
\hline Latvia & 3,965 & \multicolumn{5}{|c|}{2011 report, no data for 2030} \\
\hline Lithuania & 3,009 & \multicolumn{5}{|c|}{ No data for 2030} \\
\hline Luxembourg & 3,297 & \multicolumn{5}{|c|}{ No data for 2030} \\
\hline Malta & \multicolumn{6}{|c|}{2011 report, no data for energy demand at all } \\
\hline Netherlands & \multicolumn{6}{|c|}{ No data publicly available } \\
\hline Poland & 56,806 & 74,641 & \multicolumn{4}{|c|}{2005 historic val } \\
\hline Portugal & \multicolumn{6}{|c|}{2011 report, no data for energy demand at all } \\
\hline Romania & \multicolumn{6}{|c|}{ Accompanying report contains no data to calculate a potential } \\
\hline Slovak Rep. & 7,084 & 11,473 & 10,687 & 787 & 6.86 & \\
\hline Slovenia & 4,833 & 6,468 & 5,429 & 1,040 & 16.07 & 2011 report \\
\hline Spain & 92,896 & 116,418 & 116,111 & 306 & 0.26 & \\
\hline Sweden & 32,432 & 33,654 & No data for sc & lario "with ad & ditional mea & ures" \\
\hline UK & 136,064 & \multicolumn{5}{|c|}{2011 report, no data for scenario "with add. measures" and for 2030} \\
\hline $\begin{array}{l}\text { Sum of } \\
\text { demand }\end{array}$ & 967,995 & & & & & \\
\hline $\begin{array}{l}\text { Sum of } \\
\text { demand in } \\
\text { Member } \\
\text { States with } \\
\text { potentials }\end{array}$ & 660,350 & 680,129 & 623,920 & 56,208 & 8.26 & \\
\hline$\%$ of total & $68.2 \%$ & & & & & \\
\hline
\end{tabular}

Source: Own table, data from http://cdr.eionet.europa.eu/ [30] 


\subsection{Energy efficiency potentials according to national studies}

Since not many studies exist which imply energy efficiency potentials in specific EU Member States by 2030, in the following, core results of studies commissioned by the governments of Germany, France and the UK are analysed and compared to country-specific results of EUwide studies. First of all, the different studies will be briefly introduced.

In Germany, the Federal Ministry of Economics and Technology commissioned a study that acted as the basis for the comprehensive Energy Concept (Energiekonzept für eine umweltschonende, zuverlässige und bezahlbare Energieversorgung), adopted in late 2010. The study "Energieszenarien für ein Energiekonzept der Bundesregierung" [36] includes a reference scenario and four different target scenarios that achieve German GHG emission reduction targets for 2020 and 2050 . The target scenarios vary mainly with regard to the assumed operating times of nuclear power plants. In this context, only scenario IA is examined closely because it comes closest to the decision to phase out nuclear power by 2022 by assuming a nuclear power plant lifetime expansion of four years.

The French study “Comment aller vers l'efficacité énergétique et la sobriété?" [37] was published in 2013 by a working group of the national council as part of a debate on the national energy transition (Débat national sur la transition énergétique). This meta study considers three energy efficiency scenarios that adhere to the French greenhouse gas reduction target of 75 per cent by 2050 ("facteur 4", compared to 1990).

The study entitled "The Energy Efficiency Strategy: The Energy Efficiency Opportunity in the UK" [38] was published by the Department of Energy and Climate Change (DECC) in 2012. By comparing the Baseline Scenario (which does not include new energy efficiency policies since the 2009 Low Carbon Transition Plan) and the Central Scenario (which contains policies included in the 2012 policy package but does not comprise the development of many further policies), efficiency potentials that can be exploited by existing and planned policies are outlined.

The final energy efficiency potentials identified in the national studies are shown in Table 4. In order to be able to assess the results of the national studies, final energy efficiency potentials obtained from EU-wide scenario studies (Fraunhofer ISI 2012 [27] and Fraunhofer ISI et al. 2009 [24]) and Monitoring Mechanism reports [30] are listed in addition to the national studies. 
Table 4. Final energy efficiency potentials in selected EU Member States in 2030 according to national studies (comparison of two scenarios) in comparison with EU-wide studies \& Monitoring Mechanism Reports

\begin{tabular}{|c|c|c|c|c|c|c|c|}
\hline \multirow{2}{*}{ Country } & \multirow{2}{*}{$\begin{array}{l}\text { Study \& } \\
\text { year of } \\
\text { publication }\end{array}$} & \multirow{2}{*}{ Scenario } & \multirow{2}{*}{$\begin{array}{l}\text { Study } \\
\text { base } \\
\text { year }\end{array}$} & \multicolumn{2}{|c|}{\begin{tabular}{|l|}
$\begin{array}{l}\text { Final energy } \\
\text { demand (ktoe) }\end{array}$ \\
\end{tabular}} & \multirow{2}{*}{\begin{tabular}{|l|} 
Potential in \\
2030 rel. to \\
Reference \\
Sc. $(\%)$ \\
\end{tabular}} & \multirow{2}{*}{$\begin{array}{l}\text { Potential in } \\
2030 \text { rel. to } \\
\text { base year } \\
\left.(\%)^{\star \star \star}\right)\end{array}$} \\
\hline & & & & \begin{tabular}{|l|} 
Base \\
year
\end{tabular} & 2030 & & \\
\hline \multirow{11}{*}{$\begin{array}{l}\text { Ger- } \\
\text { many }\end{array}$} & \multirow{2}{*}{\begin{tabular}{|l} 
Energieszenari \\
en 2010 \\
\end{tabular}} & Reference scenario ${ }^{*}$ ) & \multirow{2}{*}{2008} & \multirow{2}{*}{217,995} & \begin{tabular}{|l|}
186,199 \\
\end{tabular} & - & 14.6 \\
\hline & & Scenario IA & & & 166,949 & 10.3 & 23.4 \\
\hline & EU Ref. 2013 & Reference scenario & 2010 & 217,362 & 187,218 & - & 13.9 \\
\hline & \multirow{2}{*}{\begin{tabular}{|l|} 
Fraunhofer \\
ISI 2012 \\
\end{tabular}} & Primes 2009 Baseline*) & \multirow{2}{*}{2007} & \multirow{2}{*}{211,000} & 199,000 & - & 5.7 \\
\hline & & Technical potential & & & 104,000 & 47.7 & 50.7 \\
\hline & \multirow{4}{*}{$\begin{array}{l}\text { Fraunhofer } \\
\text { ISI et al. } 2009\end{array}$} & Reference scenario ${ }^{\star}{ }^{\star \star}$ ) & \multirow{4}{*}{2005} & \multirow{4}{*}{218,719} & 235,628 & - & -7.7 \\
\hline & & LPI potential & & & \begin{tabular}{|l|}
185,955 \\
\end{tabular} & 21.1 & 15.0 \\
\hline & & HPI potential & & & \begin{tabular}{|l|}
150,050 \\
\end{tabular} & 36.3 & 31.4 \\
\hline & & Technical potential & & & \begin{tabular}{|l|}
122,837 \\
\end{tabular} & 47.9 & 43.8 \\
\hline & \multirow{2}{*}{\begin{tabular}{|l|} 
Monitoring \\
Mechanism \\
2013
\end{tabular}} & With measures ${ }^{\star}$ ) & \multirow{2}{*}{2010} & \multirow{2}{*}{216,373} & 194,800 & - & 10.0 \\
\hline & & With add. measures & & & 175,111 & 10.1 & 19.1 \\
\hline \multirow{13}{*}{ France } & \multirow{4}{*}{$\begin{array}{l}\text { Comment aller } \\
\text { vers l'efficacité } \\
\text { énergétique et } \\
\text { la sobriété? } \\
2013 \\
\end{array}$} & DGEC AME *) & 2010 & \begin{tabular}{|l|}
156,148 \\
\end{tabular} & 155,718 & - & 0.3 \\
\hline & & DGEC F4 & 2010 & 156,062 & 131,212 & 15.7 & 15.9 \\
\hline & & Ademe & 2010 & 150,989 & 123,216 & 20.9 & 18.4 \\
\hline & & NégaWatt & 2010 & 156,062 & 107,653 & 30.9 & 31.0 \\
\hline & \begin{tabular}{|l|} 
EU Ref. 2013 \\
\end{tabular} & \begin{tabular}{|l|} 
Reference scenario \\
\end{tabular} & 2010 & 158,771 & 147,937 & - & 6.8 \\
\hline & \multirow{2}{*}{\begin{tabular}{|l|} 
Fraunhofer \\
ISI 2012 \\
\end{tabular}} & Primes 2009 Baseline*) & \multirow{2}{*}{2007} & \multirow{2}{*}{155,000} & 156,000 & - & -0.6 \\
\hline & & Efficiency scenario & & & 86,000 & 44.9 & 44.5 \\
\hline & \multirow{4}{*}{$\begin{array}{l}\text { Fraunhofer } \\
\text { ISI et al. } 2009\end{array}$} & Reference scenario ${ }^{\star}{ }^{\star \star}$ ) & \multirow{4}{*}{2005} & \multirow{4}{*}{156,187} & 180,331 & - & -15.5 \\
\hline & & LPI potential & & & 147,666 & 18.1 & 5.5 \\
\hline & & HPI potential & & & \begin{tabular}{|l|}
123,071 \\
\end{tabular} & 31.8 & 21.2 \\
\hline & & Technical potential & & & 99,969 & 44.6 & 36.0 \\
\hline & & With measures *) & & & 129,901 & - & 3.7 \\
\hline & $\begin{array}{l}\text { Mechanism } \\
2013\end{array}$ & With add. measures & 2010 & 134,832 & 111,410 & 14.23 & 17.4 \\
\hline & The Energy & Baseline policies sc. $^{*}$ ) & & 154,808 & 165,090 & - & -6.6 \\
\hline & $\begin{array}{l}\text { Efficiency } \\
\text { Strategy } 2012\end{array}$ & Central scenario & 2008 & 154,859 & 146,432 & 11.0 & 5.4 \\
\hline & \begin{tabular}{|l} 
EU Ref. 2013 \\
\end{tabular} & Reference scenario & 2010 & 142,950 & 130,740 & - & 8.5 \\
\hline UK & \begin{tabular}{|l} 
Primes 2009 \\
\end{tabular} & Baseline scenario & 2005 & 144,370 & 140,266 & - & 2.8 \\
\hline & & Reference scenario ${ }^{\star}{ }^{\star \star}$ ) & & & 161,971 & - & -7.4 \\
\hline & Fraunhofer & LPI potential & & & 134,498 & 17.0 & 10.8 \\
\hline & ISI et al. 2009 & HPI potential & 2005 & 150,758 & 114,583 & 29.3 & 24.0 \\
\hline & & Technical potential & & & 92,393 & 43.0 & 38.7 \\
\hline
\end{tabular}

*) Scenario used as a reference for calculating final energy savings potential for 2030

**) Reference scenario based on the EU's so-called Primes 2007 Baseline scenario [39]

***) Negative savings indicate increased demand versus the base year or reference scenario

Source: Own table, studies analysed: [36], [37], [38], [40], [41]

\section{DISCUSSION}

Although determining the extent of national energy efficiency potentials for 2030 on the basis of existing studies proved to be a difficult task, by attempting to do so we gained some important insights.

Our analysis shows that comparable quantitative information on the potentials for final energy efficiency for individual EU Member States in 2030 is difficult to obtain. At present, the best data basis can either be derived from a small number of EU-wide studies that disclose country-by-country data for final energy demand or from the policy projections provided by about 10 Member States within the EU's GHG Monitoring Mechanism or from the small 
number of national energy scenario studies available ${ }^{3}$. Figure 1 provides an overview of the energy efficiency potentials derived from the three different types of studies for the specific EU Member States.

Figure 1. Energy efficiency potentials*) in the EU Member States until 2030 according to different energy and climate scenario studies, in per cent of final energy demand reduction versus the respective baseline

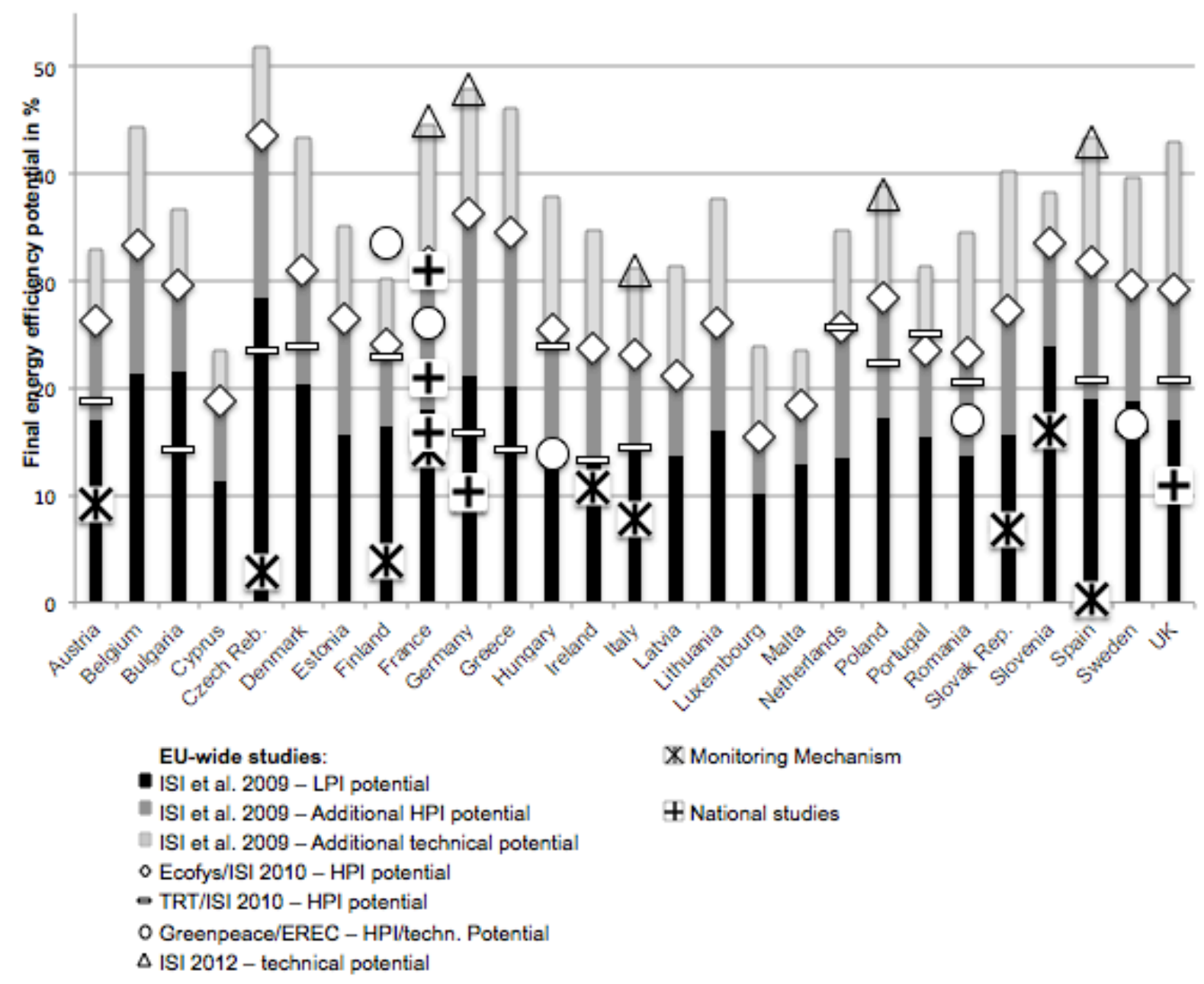

*) Most studies only provide data for a few selected countries; efficiency potentials for every EU Member State are only available from ISI et al. 2009 [24] and Ecofys/Fraunhofer ISI 2010 [28]

Source: Own figure, studies and data analysed: [24], [25], [26], [27], [28], [30], [31], [32], [33], [34], [35], [36], [37], [38]

In accordance with Fraunhofer ISI et al. 2009 [24], energy efficiency potentials are categorised ranging from "low policy intensity" and "high policy intensity" to "technical". As expected, the estimates of potentials given differ significantly depending on the category for which potentials are provided. However, as long as the studies are not based on each other, the results for individual countries also differ markedly between studies, even if the same category of efficiency potentials was used. (We provide no further details by demand sector

\footnotetext{
${ }^{3}$ While we cannot claim that we were able to identify all relevant national studies, it seems to be a fact that for some Member States there are several scenario studies while for others no (accessible) studies exist.
} 
here. However, potentials also vary substantially at the sectoral level without any clear patterns visible.)

Numerically, savings potentials derived from Monitoring Mechanism reports tend to be very low, close to or even considerably below the low policy intensity savings potential as indicated by Fraunhofer ISI et al. 2009. This could either indicate low emphasis on energy efficiency measures in the "with additional measures" projections or it could mean that already a significant amount of energy efficiency measures has been factored into the "with existing measures" projections. Evidence in favour of the latter interpretation is provided by a comparison of absolute energy consumption values for the "with existing measures" scenarios in 2030 with different "baseline" scenarios calculated at similar points in time for the same country. As displayed in Table 3, "with existing measures" projections expect significantly lower final energy demand than other baseline scenarios. This at least indicates that they already assume a partial exploitation of energy efficiency potentials and that "with additional measures" projections are more ambitious than their relative final energy efficiency potentials appear. Germany's and France's submission under the EU MM, e.g., only project 10 and 14 per cent final energy savings versus the "With measures" projection, i.e. its baseline scenario. The baseline scenario's final energy consumption in 2030 is, however, smaller than that of the study by Fraunhofer ISI et al. 2009.

Analysing the potentials derived from government-commissioned national studies (Table 4), efficiency potentials for France range from 16 per cent to 31 per cent, while those given for Germany (10 per cent) and the UK (11 per cent) are significantly smaller. These differences, however, must be interpreted with caution because the reference scenarios in the national studies vary substantially in terms of the assumed development of final energy consumption. In order to take account of these differences in baselines, we use the Reference scenario by Fraunhofer ISI 2012 [27] (which is based on the EU's so-called Primes 2009 Baseline scenario [41]) as a benchmark. It uses the same definition of baseline for all countries, and was compiled at a similar time as the studies under comparison. ${ }^{4}$

- Comparing both, the German national reference (of 15 per cent versus the base year) assumes significantly higher final energy savings than the Fraunhofer ISI 2012 reference (at about 6 per cent versus the base year). Hence, the policy scenario's energy efficiency potential by 2030 is much more ambitious than it appears. In terms of the classification by Fraunhofer ISI et al. 2009, the policy scenario could be categorised as a low policy intensity scenario.

- In the case of France, the Fraunhofer ISI 2012 reference and the reference scenario in the national study expect roughly the same development versus the base year. Their underlying assumptions could be compared quite well. Thus, the above-mentioned efficiency potentials derived from the national study are well comparable with efficiency potentials implied in the EU-wide scenario studies.

- For the UK, however, the national reference expects a final energy demand growth of 6.6 per cent until 2030 versus the base year. This is much higher than the 2.8 per cent savings expected in the Primes 2009 baseline [41], but is in line with the Primes 2007 baseline [39] that was conducted before the financial crisis of 2008. It is, however, unclear why

\footnotetext{
${ }^{4}$ Data from the most recent Reference scenario on trends in EU energy, transport and GHG emissions to 2050 from 2013 ([40], the successor of the Primes 2009 study [41]) is also included in Table 4 to show that if national scenario studies were compared with more up-to-date data, the resulting energy efficiency potentials would be smaller. This is because the 2013 baseline takes into account the impact of efficiency policies implemented after the publication of the 2009 baseline and the national studies.
} 
the UK study expects such a high demand growth in spite of the dampening effects of the financial crisis and in contradiction to the more recent Primes 2009 baseline.

Thus, the energy efficiency potential derived for 2030 is considerably smaller than 11 per cent. This appears to be quite low even though only policies discussed in 2012 have been included in the scenario calculation and thus also the calculation of efficiency potentials for 2030 .

It has, however, to be noted that the information on the energy efficiency potential of individual EU Member States that can be gleaned from these sources is comparable only to a limited extent. This is because the various studies (unless they are just updates of earlier ones) refer to significantly different reference developments and use different definitions of potentials. Data provided by the studies was insufficient to correct for these differences in definitions.

\section{CONCLUSION}

In spite of widespread insufficiencies in the database, the available evidence from several studies indicates that the political target of improving overall energy efficiency at EU level by at least 27 per cent by 2030, as decided by the European Council in October 2014, appears to be quite feasible with high policy effort. While the studies analysed agree on the existence of significant technical and economic potentials for final energy efficiency, they vary substantially with regard to their estimates at national and sectoral levels. Figure 1 shows that there may be significant differences between efficiency potentials in the Member States. However, the scope of these differences can be considered highly uncertain, given the huge variations between the Member States and the inconsistencies in the existing data. Thus, the information about energy efficiency potentials available in the EU Member States as derived here is of limited significance to benchmark existing or future national energy efficiency targets.

In order to improve current energy efficiency policies, an important strategy would be to introduce actions ensuring higher comparability and level of detail of information sources on energy efficiency potentials in all EU Member States. Improved databases would also reduce the Member States' opportunities to conceal a lack of ambitiousness regarding energy efficiency.

Since energy-related GHG emissions have to approach zero by around mid-century to mitigate global warming to around $2^{\circ} \mathrm{C}$, long-term strategies gain increasingly in importance. ${ }^{5}$ Future actions should therefore consider not only the next five years but should be imbedded in long-term strategies, keeping future long-term objectives in mind. At the time of the literature research for this study, most EU Member States provided data on energy efficiency targets for 2016 and 2020 but only very few for 2030 .

In order to foster progress on improved databases, we see mainly two approaches for the EU that could complement each other if implemented in a coherent way:

- The first is a study-based approach of improving bottom-up data on energy efficiency potentials. It could be implemented via new, thorough bottom-up studies based on a consistent and comparable methodology for all Member States. Such studies could provide technical guidance and improve methodological understanding of data and data sources. They should, however, be complemented by studies

\footnotetext{
${ }^{5}$ E.g., scenario studies published in the framework of the Deep Decarbonization Pathways Project [42] aim at „filling a key gap in climate policy“ by providing „a critical, missing long-term framework for informing and coordinating policy and business decisions".
} 
analysing energy efficiency potentials in all demand side sectors conducted by or on behalf of the EU Member States, as such studies would be better suited to take into account specific national circumstances. If these studies were conducted by using harmonised methodologies, they could provide additional standardised and comparable data and possibly deeper insights into national specifities. Furthermore, they would serve as a capacity building tool among Member States.

- More pragmatic would be the implementation of a reporting approach. It could use the Monitoring Mechanism, the preparation of policies to implement EU directives on energy efficiency (EED, EPBD, etc.) and their impact evaluations as well as the reports due under the NEEAPs to generate more data that can be compared more easily. For this purpose, the usage of specific common definitions of potentials and data by the Member States should be introduced and made mandatory. Therefore, it would be necessary to define legal terms stated in the directives in further detail to narrow the scope for interpretation (also suggested by Schlomann et al. [6]). By these mechanisms, governments would be required to gather data in more compatible formats. If this data was made available for the general public in a transparent way (e.g. on an EU website) and for free, it would allow for comparisons between the different EU Member States and enable further scientific analyses of the potentials.

If measures to improve the availability and quality of data and reporting on demand side energy efficiency in all EU Member States are implemented, the data can also be set in context. It could, e.g., be compared to the impact resulting from inaction, i.e. the costs of remaining energy inefficiency. Thus, the introduction of reporting duties on opportunity costs, e.g. in the context of the NEEAPs, should also be considered. Such reporting would highlight the huge amount of resources wasted due to a lack of energy efficiency policies in certain areas or lack of ambition in regulations and/or their implementation.

\section{ACKNOWLEDGEMENT}

The article is based on research funded by the German Federal Ministry for the Environment, Nature Conservation, Building and Nuclear Safety in the context of the project "Climate Protection and Efficiency Policies in the European Union", FKZ UM1241161. The responsibility for the content of this article rests solely with the authors and the opinions expressed are those of the individual authors.

\section{REFERENCES}

[1] European Commission. Communication from the Commission to the European Parliament and the Council: Energy Efficiency and its contribution to energy security and the 2030 Framework for climate and energy policy. COM(2014) 520 final. Brussels: 2014.

[2] International Energy Agency. Energy Efficiency Market Report 2014: Market Trends and Medium-Term Prospects. Paris: 2014.

[3] European Union. EUR-Lex: Access to European Union law. Document 32012L0027. http://eur-lex.europa.eu/legal-content/EN/TXT/?uri=celex:32012L0027, last access 15 December 2015.

[4] European Council. Conclusions on 2030 Climate and Energy Policy Framework. SN 79/14. Brussels 23th and 24th October 2014. 
[5] European Commission. Energy Efficiency Directive: National energy efficiency targets. http://ec.europa.eu/energy/en/topics/energy-efficiency/energy-efficiency-directive, last access 15 December 2015.

[6] Schlomann B, Rohde C, Plötz P. Dimensions of energy efficiency in a political context. Energy Effic 2015; 1: 97-115.

[7] Kwong QJ, Ali Y. A review of energy efficiency potentials in tropical buildings Perspective of enclosed common areas. Renewable and Sustainable Energy Reviews 2011; 9: 4548-53.

[8] Tian J, Shi H, Li X, Chen L. Measures and potentials of energy-saving in a Chinese fine chemical industrial park. Energy 2012; 1: 459-70.

[9] Sivasakthivel T, Murugesan K, Sahoo PK. A study on energy and $\mathrm{CO}_{2}$ saving potential of ground source heat pump system in India. Renew and Sustain Energy Rev 2014; 32: 278-93.

[10] Rosas-Flores JA, Rosas-Flores D, Fernández Zayas JF. Potential energy saving in urban and rural households of Mexico by use of solar water heaters, using geographical information system. Renew and Sustain Energy Rev 2016; 53: 243-52.

[11] Lu S, Lu C, Tseng K, Chen F, Chen C. Energy-saving potential of the industrial sector of Taiwan. Renew and Sustain Energy Rev 2013; 21: 674-83.

[12] Fleiter T, Fehrenbach D, Worrel E, Eichhammer W. Energy efficiency in the German pulp and paper industry - A model-based assessment of saving potentials. Energy 2012; 40: 8499.

[13] Lechtenböhmer S, Schüring A. The potential for large-scale savings from insulating residential buildings in the EU. Energy Effic 2011; 2: 257-70.

[14] Almeida A de, Fonseca P, Schlomann B, Feilberg N. Characterization of the household electricity consumption in the EU, potential energy savings and specific policy recommendations. Energy and Build 2011; 8: 1884-94.

[15] Pakula C, Stamminger R. Energy and water savings potential in automatic laundry washing processes. Energy Effic 2015; 2: 205-22.

[16] Almeida A de, Santos B, Bertoldi P, Quicheron M. Solid state lighting review - Potential and challenges in Europe. Renew and Sustain Energy Rev 2014; 34: 30-48.

[17] Tetri E, Sarvaranta A, Syri S. Potential of new lighting technologies in reducing household lighting energy use and $\mathrm{CO}_{2}$ emissions in Finland. Energy Effic 2014; 4: 559-70.

[18] Patterson MG. What is energy efficiency: Concepts, indicators and methodological issues. Energy Policy 1996; 5: 377-90.

[19] Fraunhofer ISI, TU Vienna, PricewaterhouseCoopers. Study evaluating the current energy efficiency policy framework in the EU and providing orientation on policy options for realising the cost-effective energy-efficiency/saving potential until 2020 and beyond. Report on behalf of DG ENER. Karlsruhe, Vienna, Rome: 2014 (revised).

[20] Liu W, Lund H, Mathiesen BV. Modelling the transport system in China and evaluating the current strategies towards the sustainable transport development. Energy Policy 2013; 58: 347-57.

[21] Melo CA de, Martino Jannuzzi $\mathrm{G}$ de. Cost-effectiveness of $\mathrm{CO}_{2}$ emissions reduction through energy efficiency in Brazilian building sector. Energy Effic 2015; 8: 815-26.

[22] Federal Ministry of Economics and Technology, Federal Ministry for the Environment, Nature Conservation and Nuclear Safety. Erster Monitoring-Bericht "Energie der Zukunft". Berlin: 2012.

[23] Wuppertal Institute for Climate Environment Energy, Ecofys, Energy Efficiency Watch. Final Report on the Evaluation of National Energy Efficiency Action Plans. Wuppertal, Cologne, Berlin: 2009. 
[24] Fraunhofer ISI, Enerdata, ISIS, TU Vienna, Wuppertal Institute for Climate Environment energy. Study on the Energy Savings Potentials in EU Member States, Candidate Countries and EEA Countries. Final Report. Karlsruhe, Grenoble, Rome, Vienna, Wuppertal 2009.

[25] Fiorello D, Stasio C de, Köhler J, Kraft M, Newton S, Purwanto J et al. The iTREN-2030 reference scenario until 2030. Deliverable 4 of iTREN-2030 (Integrated transport and energy baseline until 2030). Project cofunded by European Commission $6^{\text {th }}$ RTD Programme. Milan: 2009.

[26] Schade W, Krail M, Fiorello D, Helfrich N, Köhler J, Kraft M et al. The iTREN-2030 Integrated Scenario until 2030. Deliverable 5 of iTREN-2030 (Integrated transport and energy baseline until 2030). Project cofunded by European Commission $6^{\text {th }}$ RTD Programme. Karlsruhe: 2010.

[27] Fraunhofer ISI. Accompanying scientific report - Contribution of energy efficiency measures to climate protection within the European Union until 2050, Concrete Paths of the European Union to the $2^{\circ} \mathrm{C}$ Scenario: Achieving the Climate Protection Targets of the EU by 2050 through Structural Change, Energy Savings and Energy Efficiency Technologies. Karlsruhe: 2012.

[28] Ecofys, Fraunhofer ISI. Energy savings 2020: How to triple the impact of energy saving policies in Europe, A contributing study to Roadmap 2050: a practical guide to a prosperous, low-carbon Europe. Karlsruhe: 2010.

[29] Greenpeace, European Renewable Energy Council. Energy [r]evolution: a sustainable EU 27 energy outlook. Brussels: 2012a.

[30] European Environment Agency. Central Data Repository. http://cdr.eionet.europa.eu, last access 24 April 2015.

[31] Greenpeace, European Renewable Energy Council. Energy [r]evolution: a sustainable Finland energy outlook. Brussels: $2012 \mathrm{~b}$.

[32] Greenpeace, European Renewable Energy Council. Energy [r]evolution: a sustainable France energy outlook. Brussels: 2012c.

[33] Greenpeace, European Renewable Energy Council. Energy [r]evolution: a sustainable Romania energy outlook. Brussels: 2012d.

[34] Greenpeace, European Renewable Energy Council. The advanced energy [r]evolution: a sustainable energy outlook for Sweden. Brussels: 2011a.

[35] Greenpeace, European Renewable Energy Council. The advanced energy [r]evolution: a sustainable energy outlook for Hungary. Brussels: 2011 b.

[36] Prognos AG, Energiewirtschaftliches Institut an der Universität zu Köln, Gesellschaft für Wirtschaftliche Strukturforschung mbH. Energieszenarien für ein Energiekonzept der Bundesregierung. Basel, Cologne, Osnabrück: 2010.

[37] Fink M, Hug F. Comment aller vers l'efficacité énergétique et la sobriété. Secrétariat general du débat national sur la transition énergétique. Brussels: 2013.

[38] Department of Energy \& Climate Change. The Energy Efficiency Strategy: The Energy Efficiency Opportunity in the UK. London: 2012.

[39] European Commission. European Energy and Transport: Trends to 2030 - Update 2007. Directorate-General for Energy and Transport. Luxembourg: 2008.

[40] European Commission. EU energy, transport and GHG emissions: trends to 2050, Reference scenario 2013. Directorate-General for Energy, Directorate-General for Climate Action, Directorate-General for Mobility and Transport. Luxembourg: 2014.

[41] European Commission. EU energy trends to 2030, Update 2009. Directorate-General for Energy. Luxembourg 2010.

[42] Deep Decarbonization Pathways Project. Research methods: Research approach. http://deepdecarbonization.org/research-methods/research-approach/, last access 15 December 2015. 